\title{
Н. ТУулИНГ
}

\section{СТРУКТУРА ВОСТОЧНОЙ ЧАСТИ ПРИБАЛТИЙСКОГО БАССЕЙА ГОРЮЧИХ СЛАНЦЕВ И ФОСФОРИТОВ}

Прибалтийский бассейн горючих сланцев (кукерситов и диктионемовых сланцев) и фосфоритов (ПБСФ) охватывает обширную территорию на склонах Балтийского щита от Западной Эстонии до Приладожья. Промышленное значение имеют месторождения фосфоритов на территории от Таллина до Веймарна, горючих сланцев-кукерситов от Раквере до Веймарна. В настоящей статье рассматривается территория от Силламяэ до Веймарна под условным названием - восточная часть бассейна. Ранее изучалась центральная часть бассейна от Тапа до Нарвы (Вахер, 1983). Автором проведен сбор материала и составлена структурная карта по детально изученной территории Ленинградского месторождения горючих сланцев и Кингисеппского месторождения фосфоритов (рис. 1) с использованием данных по самой восточной части Әстонского месторождения сланцев и Нарвскому месторождению фосфоритов (Вахер, 1983). В общих чертах результаты структурного анализа Ленинградского месторождения и изучения блокового строения Прибалтийского сланцевого бассейна опубликованы ранее (Пуура и др., 1986).

Принадлежность данной территории к региональным тектоническим элементам Русской плиты изучена разными авторами. Восточную часть Эстонского месторождения рассматривают в составе Эстонской моноклинали на южном склоне Балтийского щита (Пуура, 1974; Тектоника Прибалтики, 1979), а моноклинальную структуру палеозойских отложений Ленинградского месторождения сланцев и Кингисеппского месторождения фосфоритов относят к юго-восточному склону щита (Пуура, 1974), к северо-западной части Московской синеклизы (Зандер, Саломон, 1971; Саломон, Егоров, 1979) или же к зоне сочленения Балтийского щита и Русской плиты (Гарбар, 1981) и т.п. В различных названиях отражаются разные терминологические подходы исследователей. Существенно то, что территория западнее р. Нарвы структурно относится к обрамлению Балтийской синеклизы, а восточнее р. Нарвы - уже к обрамлению Московской синеклизы.

Изучаемую территорию характеризует свойственное для плит древних платформ двухчленное строение геологического разреза. На эписвеко-карельском кристаллическом фундаменте с резким угловым несогласием залегает слабодислоцированный платформенный чехол мощностью 200-500 м, состоящий из терригенных и карбонатных пород вендского (валдайская серия), кембрийского, ордовикского и девонского возраста, и рыхлых четвертичных отложений (рис. 2). Разрез осадочного чехла расчленяется на структурные комплексы (этажи), разделенные несогласиями и отличающиеся по тектоническому плану осадконакопления. Принципы наименования выделяемых подразделений у прибалтийских (Пуура, Мардла, 1972; Тектоника Прибалтики, 1979) и ленинградских (Зандер, Саломон, 1971; Саломон, Егоров, 1979) авторов различны. Ленинградские исследователи рассматривают весь разрез венда и кембрия в пределах одного структурного яруса, эстонские авторы поме- 


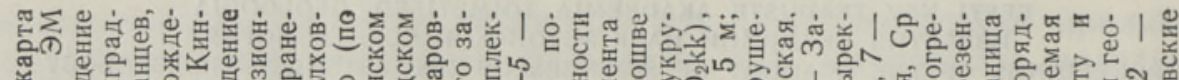

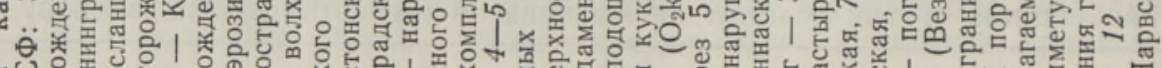

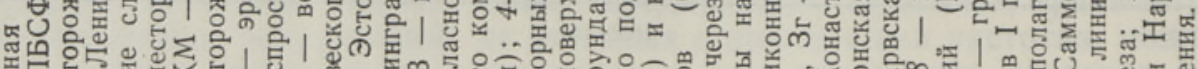

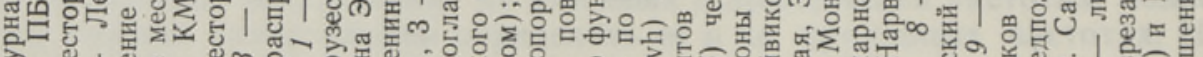

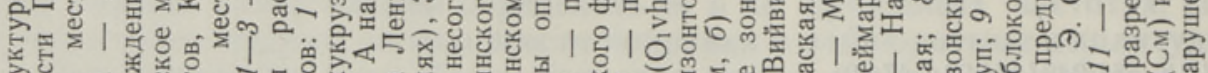

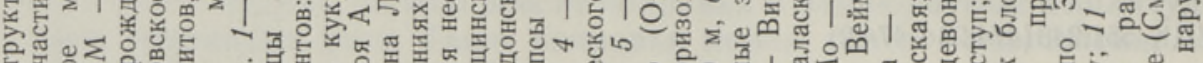
U.

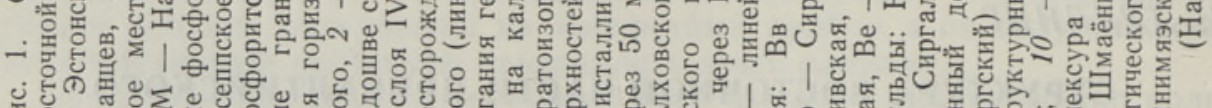

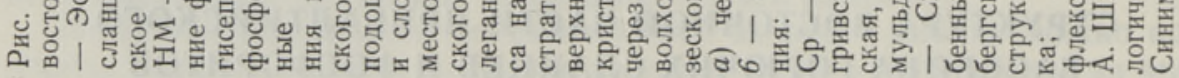

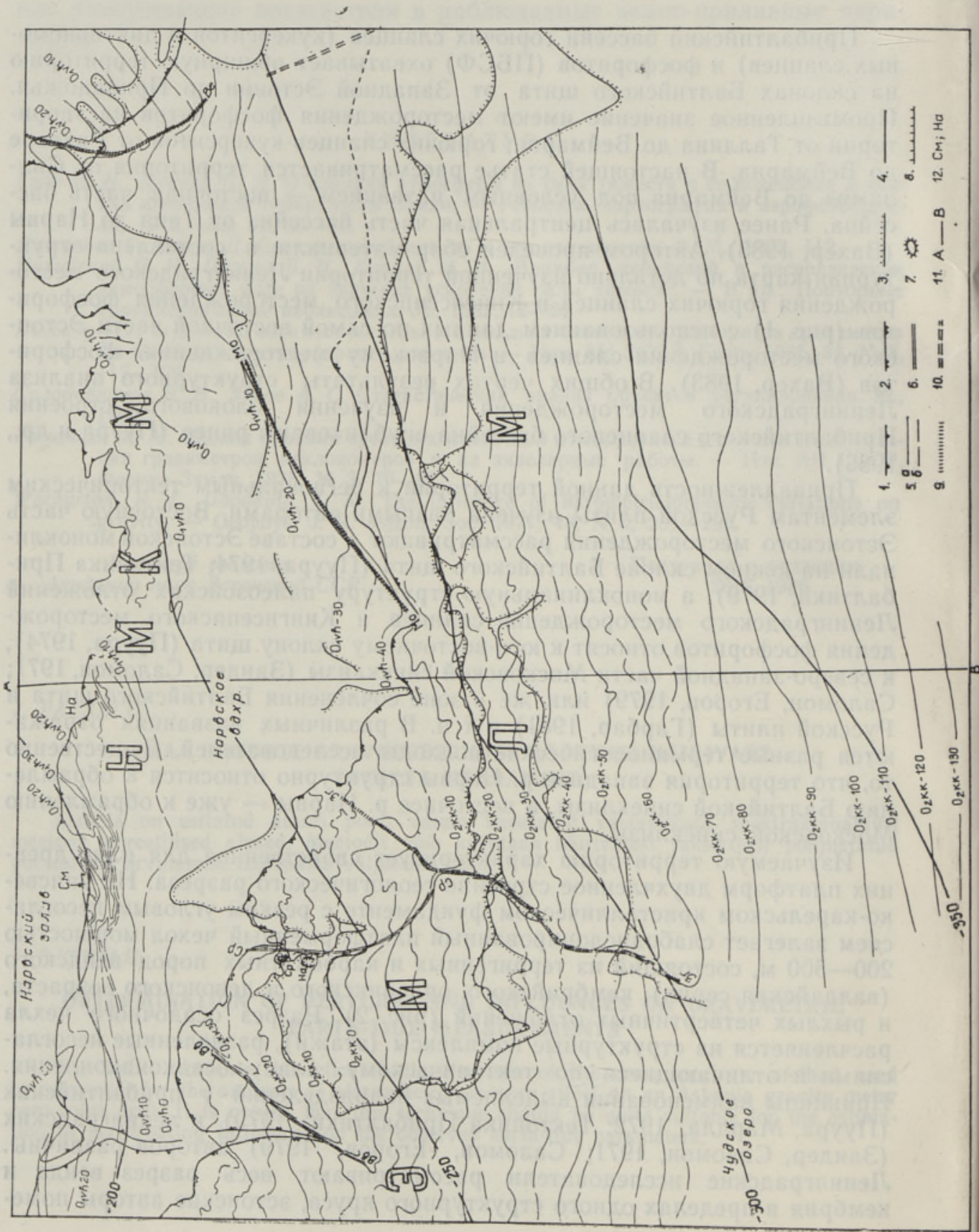




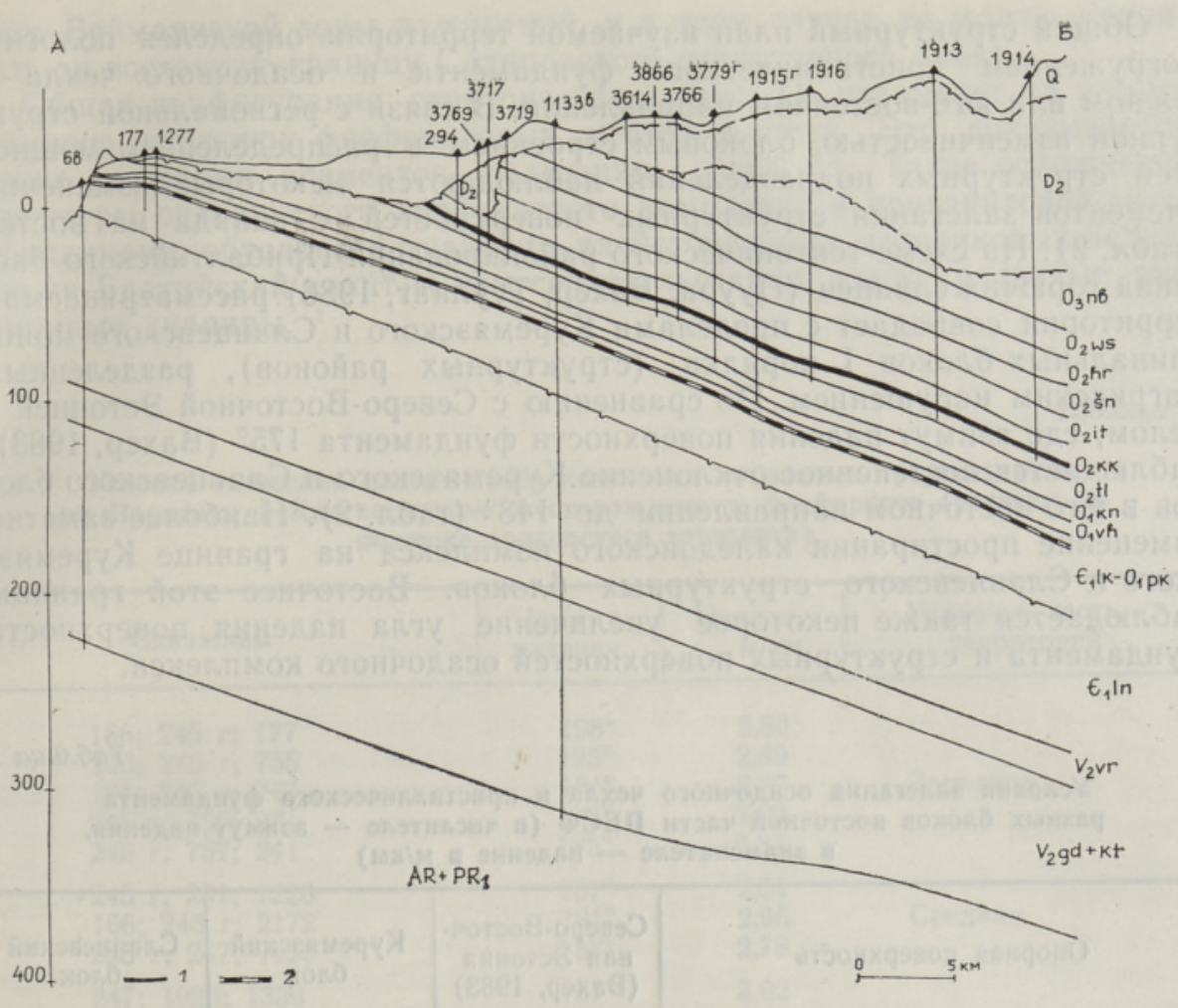

Рис. 2. Геологический разрез по линии А-Б; 1 - залежь кукерсита, 2 - фосфоритоносные отложения.

щают разделенный заметным несогласием маломощный, с многочисленными перерывами комплекс послебалтийского кембрия в каледонский структурный комплекс (табл. 1). Сланценосная и фосфоритоносная толщи залегают внутри каледонского структурного комплекса (путиловского яруса) и имеют конформную с ним структуру.

Таблица 1

\section{Сопоставление схем структурного расчленения осадочного чехла восточной части ПБСФ}

\begin{tabular}{|c|c|c|c|c|}
\hline \multirow{2}{*}{$\begin{array}{c}\text { Структурный } \\
\text { комплекс } \\
\text { Северной Прибал- } \\
\text { тики (Пуура, } \\
\text { Мардла, 1972) }\end{array}$} & \multicolumn{2}{|c|}{ Стратиграфический объем } & \multirow{2}{*}{$\begin{array}{c}\text { Структурный } \\
\text { ярус Ленин- } \\
\text { градской } \\
\text { области } \\
\text { (Саломон, } \\
\text { Егоров, 1979) }\end{array}$} & \multirow{2}{*}{$\begin{array}{c}\text { Формации } \\
\text { осадочного } \\
\text { чехла }\end{array}$} \\
\hline & $\begin{array}{l}\text { эстонские } \\
\text { авторы }\end{array}$ & $\begin{array}{c}\text { ленинградские } \\
\text { авторы }\end{array}$ & & \\
\hline Герцинский & \multicolumn{2}{|c|}{ Средний девон } & Вологодский & $\begin{array}{l}\text { Терригенная, } \\
\text { терригенно- } \\
\text { карбонатная }\end{array}$ \\
\hline \multirow[t]{2}{*}{ Каледонский } & \multirow{2}{*}{$\begin{array}{l}\text { Послебалтий- } \\
\text { ский кембрий, } \\
\text { ордовик }\end{array}$} & Ордовик & Путиловский & $\begin{array}{l}\text { Терригенная, } \\
\text { карбонатная }\end{array}$ \\
\hline & & \multirow[t]{2}{*}{ Венд, кембрий } & \multirow[t]{2}{*}{ Ленинградский } & \multirow[t]{2}{*}{ Терригенная } \\
\hline Байкальский & $\begin{array}{l}\text { Венд, нижний } \\
\text { кембрий (бал- } \\
\text { тийская серия) }\end{array}$ & & & \\
\hline
\end{tabular}


Общий структурный план изучаемой территории определен пологим погружением кристаллического фундамента и осадочного чехла в южном или юго-восточном направлении. В связи с региональной структурной изменчивостью, блоковым строением и распределением мощностей структурных подразделений наблюдаются некоторые изменения элементов залегания структурных поверхностей с запада на восток (табл. 2). На схеме тектонического районирования Прибалтийского бассейна горючих сланцев (Пуура, Вахер, Туулинг, 1986) рассматриваемая территория совпадает с пределами Куремяэского и Сланцевского моноклинальных блоков I порядка (структурных районов), разделенных Загривским нарушением. По сравнению с Северо-Восточной Әстонией в целом, где азимут падения поверхности фундамента $175^{\circ}$ (Вахер, 1983), наблюдается постепенное отклонение Куремяэского и Сланцевского блоков в юго-восточном направлении до $148^{\circ}$ (табл. 2). Наиболее заметно изменение простирания каледонского комплекса на границе Куремяэского и Сланцевского структурных блоков. Восточнее этой границы наблюдается также некоторое увеличение угла падения поверхности фундамента и структурных поверхностей осадочного комплекса.

Таблица 2

Условия залегания осадочного чехла и кристаллического фундамента разных блоков восточной части ПБСФ (в числителе - азимут падения, в знаменателе - падение в м/км)

\begin{tabular}{c|c|c|c}
\hline Опорная поверхность & $\begin{array}{c}\text { Северо-Восточ- } \\
\text { ная Эстония } \\
\text { (Вахер, 1983) }\end{array}$ & $\begin{array}{c}\text { Куремяэский } \\
\text { блок }\end{array}$ & $\begin{array}{c}\text { Сланцевский } \\
\text { блок }\end{array}$ \\
\hline
\end{tabular}

Подошва наровского горнзонта

Подошва кукрузеского горизонта

Подошва азериского горнзонта

Подошва волховского горизонта

Подошва лонтоваского горизонта

Поверхность фундамента

$\begin{array}{lll}- & - & \frac{168^{\circ}}{2,1} \\ \frac{182^{\circ}}{2,8} & \frac{176^{\circ}}{2,6} & \frac{166^{\circ}}{3,3} \\ \frac{182^{\circ}}{2,8} & \frac{177^{\circ}}{2,6} & \frac{167^{\circ}}{3,4} \\ \frac{182^{\circ}}{2,9} & \frac{177^{\circ}}{2,7} & \frac{169^{\circ}}{3,3} \\ \frac{183^{\circ}}{2,7} & \frac{180^{\circ}}{3,3} & \frac{167^{\circ}}{3,0} \\ \frac{175^{\circ}}{2,4} & \frac{164^{\circ}}{2,0} & \frac{148^{\circ}}{3,1}\end{array}$

Представляет интерес местоположение и структурные особенности Нарвского и Кингисеппского месторождений фосфоритов в отношении Куремяэского и Сланцевского структурных блоков, ранее выделенных только в сланцевом бассейне. Загривское нарушение постепенно выклинивается к северной границе Ленинградского месторождения и уже не влияет на структуру фосфоритоносной зоны. Условия залегания каледонского комплекса на последних месторождениях близки к таковым Куремяэского структурного блока. По этой причине условную юго-восточную границу Куремяэского структурного блока следует провести по кулисообразно расположенной серии зон нарушений - Загривской, Монастырекской и Веймарнской. В них, особенно в последней, происходят наиболее заметные изменения элементов залегания. По местоположению и простиранию, по результатам геологического картирования Э. Саммета и А. Шмаёнка, намечаемую вдоль восточного берега р. Луги флексуру (рис. 1), видимо, следует считать юго-восточным продолже- 
нием Веймарнской зоны нарушений, и в этом случае ее можно приниматъ за восточную границу Сланцевского структурного блока.

Общая конфигурация стратоизогипс (рис. 1) указывает на весьма сложную структуру фосфоритовых месторождений. Это доказывается также расчетами элементов залегания (табл. 3). Такое осложнение структуры ордовикского карбонатного комплекса в приглинтовой зоне, по-видимому, обусловлено напором плейстоценовых материковых ледников на Балтийский глинт, о чем свидетельствуют также развитые там глиняные диапиры.

Таблица 3

\begin{abstract}
Условия залегания каледонского комплекса по разным треугольникам на Нарвском и Кингисеппском месторождениях фосфоритов (расчеты по подошве волховского горизонта)
\end{abstract}

\begin{tabular}{c|c|c|c}
\hline Скважины & $\begin{array}{c}\text { Азнмут } \\
\text { падення }\end{array}$ & $\begin{array}{c}\text { Наклон, } \\
\text { м/км }\end{array}$ & $\begin{array}{c}\text { Условная часть } \\
\text { территорнй }\end{array}$ \\
\hline 166;245 г; 177 & $195^{\circ}$ & 2,80 & \\
$166 ; 245$ г; 755 & $195^{\circ}$ & 2,89 & Западная \\
$166 ; 245$ г; 247 & $181^{\circ}$ & 2,87 & \\
245 г; $755 ; 231$ & $183^{\circ}$ & 3,09 & \\
245 г; $757 ; 241$ & $185^{\circ}$ & 2,81 & \\
245 г; $231 ; 1226$ & $187^{\circ}$ & 2,51 & Средняя \\
$166 ; 245$ r; 2172 & $181^{\circ}$ & 2,96 & \\
245 г; $247 ; 1138$ & $183^{\circ}$ & 2,78 & \\
$247 ; 1024 ; 1353$ & $167^{\circ}$ & 3,02 & Восточная \\
$241 ; 757 ; 1284$ & $174^{\circ}$ & 2,86 & \\
$231 ; 1266 ; 1284$ & $171^{\circ}$ & 2,96 & Среднее \\
$755 ; 1393 ; 1266$ & $158^{\circ}$ & 2,79 & \\
\hline $166 ; 231 ; 1353$ & $175^{\circ}$ & 2,34 & \\
& & &
\end{tabular}

Типизация нарушений каледонского комплекса Северо-Восточной Әстонии разработана Р. Вахером. Она может быть распространена на весь бассейн (Пуура и др., 1986). В восточной части ПБСФ обнаружены следующие типы нарушений: 1) зоны линейных нарушений I и II порядка, 2) зоны трещиноватости, 3) изометрические складки, 4) глиняные диапиры.

Линейные нарушения разбивают месторождения на отдельные блоки, что осложняет раскройку шахтных полей и ведение горных работ. Сводные данные о линейных зонах нарушений в восточной части ПБСФ приведены в табл. 4. Не останавливаясь на ранее описанных нарушениях Северо-Восточной Әстонии, рассмотрим подробнее такие нарушения в северо-западной части Ленинградской области.

Наиболее детально изученная Загривская зона линейных нарушений известна с 1950-х гг., разбурена 7 профилями скважин. Азимут простирания $0-40^{\circ}$, ширина $1-2$ км, длина - более 22 км. Не исключено ее дальнейшее продолжение на юго-запад (рис. 1). На разрезе четко выделяется опущенный западный блок с синклиналью, приподнятый восточный блок с пологой антиклиналью, а также смыкающий флексурообразный изгиб (рис. 3). Вертикальное смещение по зоне достигает 16 м. Доминирующим структурным элементом оказывается флексура, амплитуда которой колеблется от 8 до 12 м. Высота синклинали и антиклинали колеблется в пределах $2-3$ и $1-4$ м соответственно.

Веймарнское нарушение было обнаружено Б. Асаткиным при разведке Веймарнского месторождения горючих сланцев в 1931 - 32 гг. Он выделил сброс северо-восточного простирания (Асаткин, 1934). Из-за 
Зоны линейных нарушений восточной части ПБСФ

\begin{tabular}{|c|c|c|c|c|c|c|c|c|c|}
\hline \multirow[b]{2}{*}{$\begin{array}{c}\text { Наименование } \\
\text { зоны }\end{array}$} & \multirow[b]{2}{*}{ Тип } & \multirow{2}{*}{$\begin{array}{c}\text { Азимут } \\
\text { прости- } \\
\text { рания }\end{array}$} & \multirow{2}{*}{ 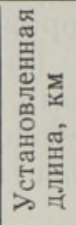 } & \multirow[b]{2}{*}{ 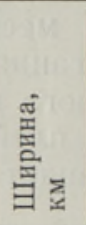 } & \multirow[b]{2}{*}{ 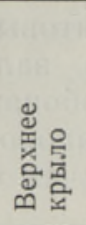 } & \multicolumn{4}{|c|}{ Вертикальная амплитуда, м } \\
\hline & & & & & & $\begin{array}{l}\text { флек- } \\
\text { суры }\end{array}$ & $\begin{array}{c}\text { анти- } \\
\text { клинали }\end{array}$ & $\begin{array}{l}\text { син- } \\
\text { кли- } \\
\text { нали }\end{array}$ & общая \\
\hline Вийвиконнаская & A & $25-55^{\circ}$ & 22 & $2-5$ & Юв & $2-3$ & $3-6$ & $1-3$ & до 11 \\
\hline Сиргалаская & $\Phi$ & $300-360^{\circ}$ & 15 & $1-3$ & B-CB & $2-6$ & $1-6$ & $1-2$ & до 10 \\
\hline Загривская & $\Phi$ & $0-40^{\circ}$ & 20 & $1-2$ & B & $8-12$ & $1-4$ & $2-3$ & до 16 \\
\hline Монастырекская & $\Phi$ & $45-70^{\circ}$ & 22 & $1-2$ & $\mathrm{C} 3$ & н. с. & н. с. & H. с. & до 13 \\
\hline Веймарнская & A & $347-28^{\circ}$ & 17 & $1-4$ & 3 & - & 16 & $1-5$ & до 16 \\
\hline
\end{tabular}

неперспективности Веймарнского месторождения долгое время новых данных практически не прибавлялось. Только в последнее время по материалам разведки Кингисеппского месторождения фосфоритов оказалось возможным уточнить строение Веймарнской нарушенной зоны, азимут простирания которой колеблется от 347 до $28^{\circ}$, длина составляет

- более 17 км. Б. Асаткин предполагал, что нарушение продолжается в северо-восточном направлении, что четко прослеживается на структурной карте (рис. 1). Очевидно его некоторое продолжение также в юговосточном направлении. Предполагаемая ширина нарушенной зоны 1 4 км. На западном крыле четко выделяется пологая синклиналь амплитудой до 5 м, которая резко переходит в смыкающее крыло флексуры амплитудой до 16 м. Именно последнюю поныне называют Веймарнским нарушением. K сожалению, достаточные данные о юго-восточном крыле нарушения пока отсутствуют.

Монастырекская зона линейных нарушений расположена между Ленинградским месторождением горючих сланцев и Кингисеппским месторождением фосфоритов. Она выделена по данным структурных построений (рис. 1). На структурной карте четко наблюдается 22-километровая нарушенная зона с азимутом простирания $45-71^{\circ}$. Скудные данные не позволяют детально охарактеризовать строение нарушения. Вероятно, что амплитуда в 13 м обусловлена в основном флексурообразным изгибом.

В течение многих лет разные авторы обращали внимание на изуче-

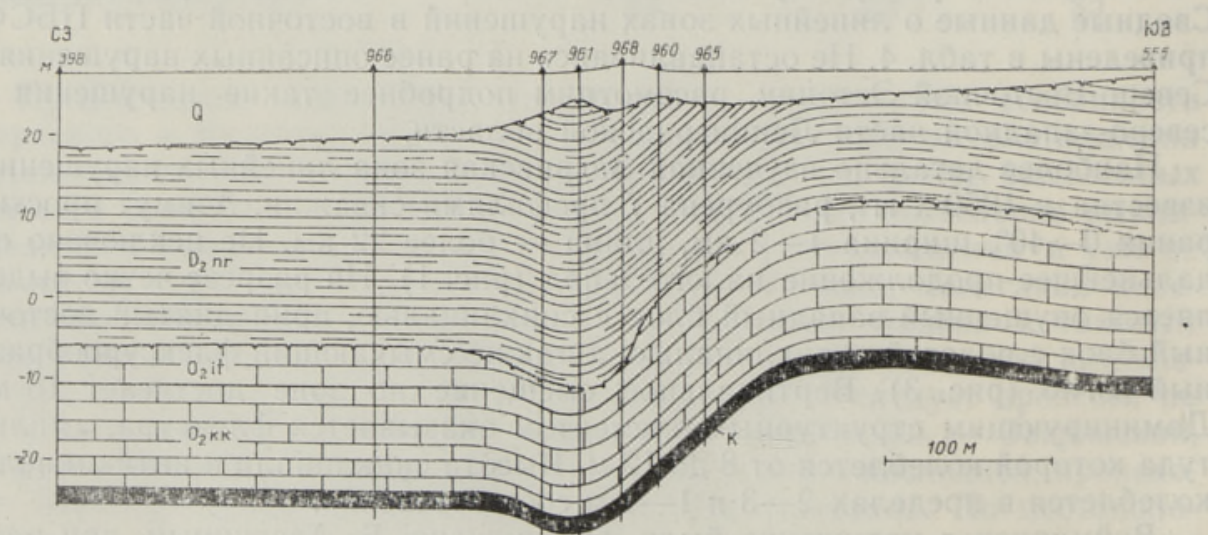

Рис. 3. Геологический разрез Загривской зоны линейных нарушений; К - пачка кукерсита. 
ние без- или малоамплитудных, часто закарстованных зон трещиноватости. Такие зоны значительно затрудняют проходку горно-подготовительных выработок, осложняют технологию ведения работ по добыче, ведут к потерям запасов сланца в целиках, отрицательно сказываются на безопасности работ и себестоимости добываемого сланца (Газизов, 1971).

Для выявления таких зон высокой эффективностью обладает дипольное электропрофилирование в зоне выхода ордовикских пород, обеспечивающее обнаружение $80 \%$ карстованных зон (Вахер, 1983). Однако в зоне развития девонских отложений эта методика малоэффективна. Строение таких зон, по данным геофизики и бурения, детально описано в восточной части Эстонского месторождения (Вахер и др., 1962; Пичугин и др., 1976), а по данным шахтной геологической службы - на Ленинградском месторождении (Газизов, 1971; Левин, 1972; Паукер, 1973).

Максимальная длина таких зон может достигать десятков и более километров, а ширина первых сотен (обычно десятки) метров. Расстояние между отдельными зонами на Эстонском месторождении в среднем 580 м (Вахер, 1983), на Ленинградском - 100-200 м (Паукер, 1973). В общих чертах интенсивность доломитизации, кавернозности и трещиноватости пород от периферии к центру увеличивается. В центре нарушений обычно находится наиболее разрушенная карстовая зона с остаточной глиной. Морфологию всей зоны осложняют мелкие складчатые нарушения и сбросы амплитудой до 3 м в наиболее нарушенной ее части. Классификация таких сбросов, флексур и поднятий разработана на примере Северо-Восточной Эстонии Ю. Хейнсалу (Хейнсалу, 1975). Азимут простирания зон трещиноватости довольно выдержанный, колеблется в пределах нескольких десятков градусов. Их средний азимут в СевероВосточной Эстонии 59॰ (Вахер, 1983) и на Ленинградском месторождении $53^{\circ}$ (Паукер, 1973), что согласуется с преобладающим северо-восточным максимумом общей трещиноватости обоих участков. Четко бросается в глаза различие их среднего азимута простирания от направления большинства главных зон трещиноватости (табл. 4). Это, вероятно, указывает на различные геологические факторы их формирования.

По данным бурения, зоны повышенной трещиноватости хорошо выделяются в карбонатной толще ордовика, но в песчано-глинистых породах прослеживаются с трудом. Пока остается малоизученным влияние главных зон нарушений и зон трещиноватости на нижнеордовикские фосфоритоносные породы и на состоявшие в них секундарные изменения. По данным геологоразведочных работ, в пределах Кингисеппского месторождения фосфоритов известны в большинстве северо-западные зоны интенсивной трещиноватости шириной $3-8 \mathrm{м}$, сопровождаемые разрывами сплошности слоев. В местах пересечения их с такими же зонами северо-восточного направления обычно образуются участки с интенсивной доломитизацией продуктивной толщи.

Моноклинальное залегание промпачки горючих сланцев и фосфоритоносного слоя местами осложнено изометрическими и брахиоскладками в поперечнике размерами $0,1-1$ км, амплитудой $0,5-5$ м и углом падения слонстости $0,5-2^{\circ}$ (Вахер, 1983). Из-за недостаточной густоты сетки буровых скважин они могут оказаться не обнаруженными даже на участках детальной разведки (буровые скважины по сети $500 \times 500$ м), но отчетливо выявляться в горных выработках (Бауков, 1968). Складки амплитудой более 5 м встречаются очень редко. В Северо-Восточной Эстонии В. Каттай детально изучены Нарвская и Сиргалаская мульды размерами в плане соответственно $0,5 \times 0,6$ км и $0,4 \times 0,4$ км. Нарвская мульда, амплитуда которой по подошве промпачки горючих сланцев 14 м, нзучена буровыми скважинами до лонтоваского горизонта, где ее 
амплитуда не сокращается, а даже немного увеличивается. Ампли́туда Сиргалаской мульды достигает 6 м. Также имеются отдельные скважины в разных районах месторождений, где наблюдается относительное погружение пластов до 10 м, что, вероятно, связано с возникновением аналогичных мульд.

Строение Нарвского месторождения фосфоритов значительно осложняют гребневидные складки (Синимяэские и Нарвские нарушения, рис. 1) высотой 30 м, длиной $1-3$ км и шириной $0,1-0,7$ км (Вахер, Мардла, 1969). Доминируют антиклинальные складки, в ядрах которых под четвертичными отложениями выходят в основном глины и алевролиты нижнего кембрия. По данным бурения, падение слоев обычно колеблется в пределах $40-70^{\circ}$, местами в керне наблюдаются многочисленные зеркала скольжения, мелкие сбросы и сдвиги. Увеличение мощности кембрийских глин и алевролитов на этих участках и повышенная их нарушенность снизу вверх при нормальном залегании вендских отложений указывает на то, что эти нарушения представляют собой глиняные диапиры, которые, вероятно, имеют глациотектоническое происхождение (Orviku, 1926; Baxep, 1983).

Поскольку геологические данные часто интерпретируются неоднозначно, точное определение возраста тектонических структур во многих случаях оказывается невозможным. При описании Веймарнского нарушения Б. Асаткин (1934) отметил, что как крылья сброса, так и сбросовая трещина покрыты спокойно и горизонтально залегающим средним девоном. Этот факт определяет досреднедевонский возраст Веймарнского нарушения и оказывает влияние на позднейшие датировки подобных нарушений (Левыкин, 1947; Гатальский, 1959 и др.) также на участках, где девонские отложения отсутствуют (Вахер и др., 1962). Обстоятельный структурный анализ всех существующих данных позволяет предполагать, что в Загривской зоне нарушены и девонские слои. На это указывает геологический разрез (рис. 3), где подошва девонских слоев следует нарушенности ордовика. Еще более отчетливо это выражается на структурной карте по подошве девонского комплекса (рис. 4), где по Загривскому нарушению соприкасаются участки с разными высотными отметками. Опускание западного участка на 10-12 м хорошо совпадает с таким же смещением каледонского структурного комплекса. Аналогично девонские слои повторяют конфигурацию ордовикских слоев в Нарвской мульде, что свидетельствует о его послесреднедевонском возрасте. Таким образом, часть нарушений имеет додевонский, а другая часть - последевонский возраст.

В конце 20-х гг. в северо-западной части Ленинградской области в рельефе ордовикских пород был установлен субширотный додевонский погребенный уступ (т. н. Везенбергский уступ), о природе которого до сих пор существуют разные мнения. Е. М. Люткевич уже в 1928 г. писал о происхождении уступа, как о результате размыва. Вывод о денудационной природе поддерживают позже и другие исследователи (Марков, 1931,1955 ; Дубарь, Левин, 1973). В ряде неопубликованных материалов есть мнения о его тектоническом происхождении. Однако обстоятельный структурный анализ позволяет опровергнуть последнее предположение (рис. 1,2$)$. По морфологии уступа и расположенной севернее его впадины можно допустить, что уступ представляет собой обрывистый склон досреднедевонской эрозионной долины. Дно ее имело наклон в сторону Московской синеклизы, следуя общему погружению всего осадочного комплекса в этом же направлении. Среднедевонская трансгрессия наполнила образовавшуюся впадину терригенным материалом. В таком положении уступ был хорошо защищен от дочетвертичной эрозии и экзарации плейстоценовыми материковыми ледниками.

В заключение отметим, что на изучаемой территории наблюдается 


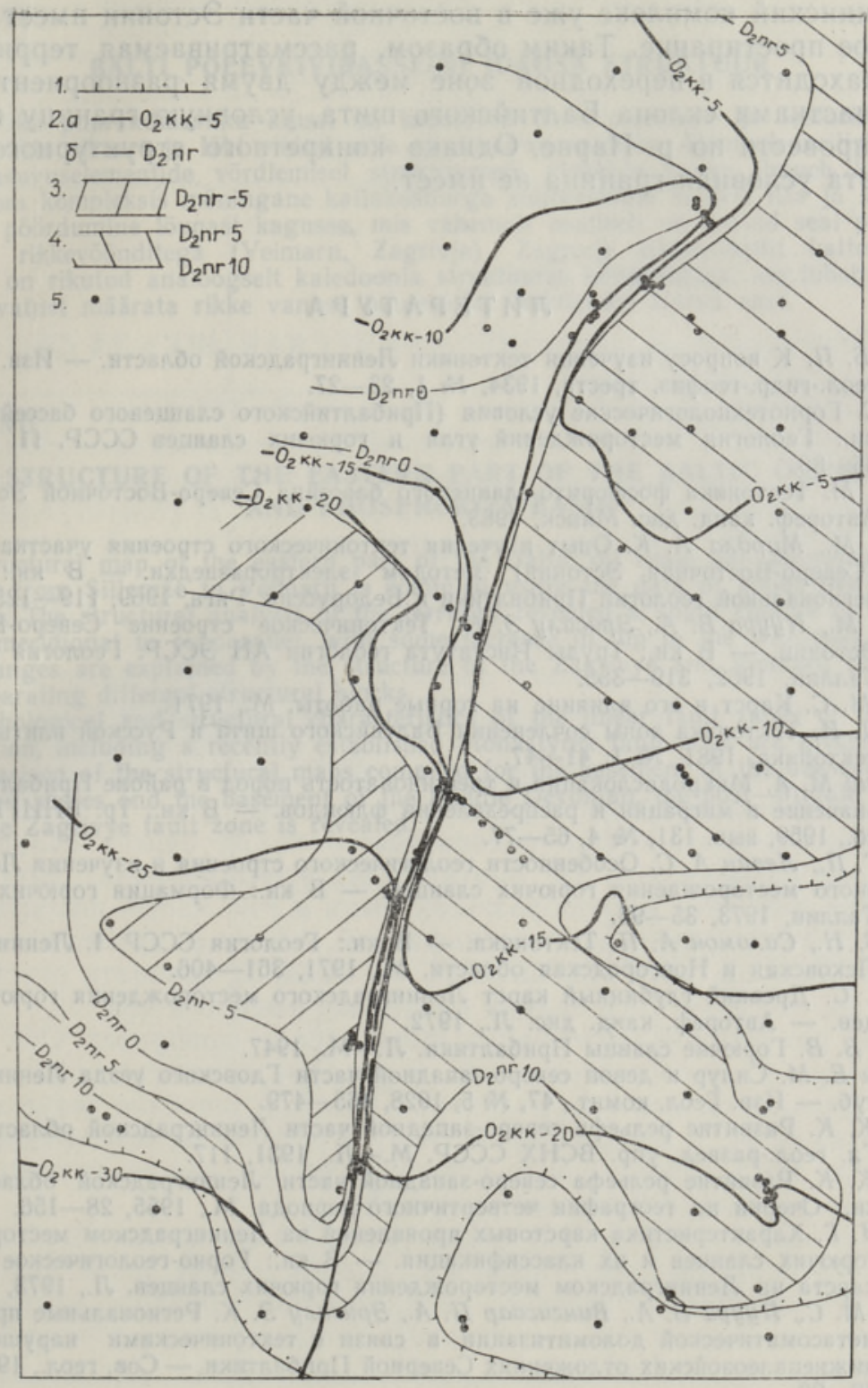

Рис. 4. Структурная схема северной части Загривской зоны линейных нарушений. 1 граница распространения среднего девона, 2 - стратоизогипсы опорных поверхностей: a) по подошве IV слоя промпачки сланцев, б) по подошве среднего девона; 3 - подошва девона на высоте ниже -5 м; 4 - подошва девона на высоте 5-10 м над у. м.; 5 буровые скважины.

постепенное изменение регионального структурного плана осадочного комплекса - отклонение его азимута падения в юго-восточном направлении и некоторое увеличение угла падения. По разным опорным поверхностям это происходило по-разному. Изогипсы поверхности фундамента (рис. 1) приобретают северо-восточное простирание уже западнее рассматриваемого района, простирание каледонского комплекса заметно отклоняется на северо-восток по Веймарнскому нарушению и менее - по Загривскому нарушению. Известно (Пуура, Мардла, 1972; Пуура, 1974), 
что герцинский комплекс уже в восточной части Әстонии имеет северовосточное простирание. Таким образом, рассматриваемая территория в целом находится в переходной зоне между двумя разноориентированными участками склона Балтийского щита, условную границу которых можно провести по р. Нарве. Однако конкретного структурного содержания эта условная граница не имеет.

\section{ЛИТ Е РА Т У Р А}

Асаткин Б. П. К вопросу изучения тектоники Ленинградской области. - Изв. Ленингр. геол.-гидр.-геофиз. треста, 1934, № 1, 23-27.

Бауков С. Горнотехнологические условия (Прибалтийского сланцевого бассейна). - В кн.: Геология месторождений угля и горючих сланцев СССР. 11. М., 1968, $85-88$.

Baxер P. М. Тектоника фосфорито-сланцевого бассейна Северо-Восточной Эстонии. Автореф. канд. дис. Минск, 1983.

Baxep P. М., Мардла A. K. Опыт изучения тектоннческого строення участка Синимяэ (Северо-Восточная Эстония) методом электроразведки. - В кн.: Вопросы региональной геологии Прибалтики и Белоруссии. Рига, 1969, 119-125.

Bахер P. М., Пуура В. А., Эрисалу Э. К. Тектоническое строение Северо-Восточной Эстонии. - В кн.: Труды Института геологин АН ЭССР. Геология палеозоя. Таллин, 1962, 319-355.

Газизов М. С. Карст и его влияние на горные работы. М., 1971.

Гарбар Д. И. Тектоника зоны сочленения Балтийского щита и Русской плиты. - Геотектоника, 1981, № 1, 41-47.

Гатальский М. А. Микродислокация и трещиноватость пород в районе Прибалтики и их значение в миграции и распределении флюндов. - В кн.: Тр. ВНИГРИ, Геол. сб., 1959, вып. 131, № 4, 65-77.

Дубарь Г. П., Левин А. С. Особенности геологического строения и изучения Ленинградского месторождения горючих сланцев. - В кн.: Формация горючих сланцев. Таллин, 1973, 35-93.

Зандер В. Н., Саломон А. П. Тектоника. - В кн.: Геология СССР. І. Ленинградская, Псковская и Новгородская области. М., 1971, 361-406.

Левин А. С. Древний глубинный карст Ленинградского месторождения горючих сланцев. - Автореф. канд. дис. Л., 1972.

Левыкин В. В. Горючне сланцы Прибалтикн. Л.-М., 1947.

Люткевич Е. М. Силур и девон северо-западной части Гдовского уезда Ленинградской губ. - Изв. Геол. комит., 47, № 5, 1928, 465-479.

Марков K. К. Развитие рельефа северо-западной части Ленинградской области. - Тр. Гл. геол.-развед. упр. ВСНХ СССР. М.-Л., 1931, 117.

Марков K. K. Развитие рельефа северо-западной части Ленинградской области. - В кн.: Очерки по географии четвертичного периода. М., 1955, 28-156.

Паукер Н. Г. Характеристика карстовых проявлений на Ленинградском месторожденин горючих сланцев и их классифнкация. - В кн.: Горно-геологическое значение карста на Ленинградском месторожденин горючих сланцев. Л., 1973, 54-79.

Пичугин М. С., Пуура В. А., Вингисаар П. А., Эрисалу Э. К. Региональные проявления метасоматической доломитизации в связи с тектоническими нарушениями в нижнепалеозойских отложениях Северной Прибалтики. - Сов. геол., 1976, № 10, $78-90$.

Пуура В. А. Структура южного склона Балтийского щита. - Автореф. канд. дис. Таллин, 1974.

Пуура В., Мардла А. Структурное расчленение осадочного чехла в Эстонии. - Изв. АН ЭССР. Хим. Геол., 1972, 21, № 1, 72-78.

Пуура В. А., Вахер Р. М., Туулинг И. И. Тектоника. - В кн.: Строение сланценосной толщи Прибалтийского бассейна горючих сланцев-кукерситов. Таллин, 1986, $55-63$.

Саломон А. П., Егоров Г. И. Объяснительная записка к тектонической карте северозападной окраины Русской плиты в масштабе 1:1500 000 и методика ее составления. Л., 1979.

Тектоника Прибалтикн. Вильнюс, 1979.

Хейнсалу Ю. Характеристика трещиноватости пород и зон геологических нарушений. В кн.: Трещиноватость в районе сланщевых шахт Эстонни и геофизические методы ее изучения. Таллин, 1975. 


\section{BALTI POLEVKIVIBASSEINI IDAOSA STRUKTUUR}

Rikkaliku puurandmestiku alusel on koostatud Balti põlevkivi- ja fosforiidibasseini idaosa struktuurikaart ja läbi viidud selle struktuurne analüüs. Alampaleosoiliste kivimikihtide lasuvuselementide võrdlemisel struktuursete plokkide kaupa ilmneb kaledoonia struktuurses kompleksis mõningane kallakusnurga suurenemine läänest itta ja selle järkjärguline pöördumine lõunast kagusse, mis vähemalt osaliselt on seotud seal paiknevate jooneliste rikkevöönditega (Veimarn, Zagrivje). Zagrivje rikkevööndit kattev devoni kompleks on rikutud analoogselt kaledoonia struktuurse kompleksiga, see lubab erinevalt varem arvatust määrata rikke vanuse nooremaks keskdevoni Narva east.

\section{TUULING}

\section{THE STRUCTURE OF THE EASTERN PART OF THE BALTIC OIL SHALE AND PHOSPHORITE BASIN}

A structural map of the eastern part of the Baltic oil shale and phosphorite basin extending from Sillamäe to Veimarn is compiled using the data of about five thousand bore-holes. The structural analysis of the territory revealed a slight change of the strike from submeridional to subparallel, with some increase in dip in the west-east direction. These changes are explained by the structure of the Zagrivye and Veimarn linear fault zones separating different structural blocks.

Morphological and structural characteristics of the linear fault zones of the Leningrad Region, including a recently established Monastyrek fault zone are given. Through the comparison of the structural maps compiled for the basement of the deepest (fourth) layer of oil shales and the basement of the Middle Devonian, the post-Middle Devonian age of the Zagrivye fault zone is revealed. 